\title{
The Narrative Arc Bends toward Justice: Storytelling in Classroom and Community
}

The paper presents practical ways in which narrative and storytelling can be used as empowering tools for students of political and social change. The perspectives and applications I discuss have emerged from work with non-traditional and minoritized students in classroom and community contexts. Thematically, the paper will focus on two key ways in which students may engage with narrative. First, students may come to understand and analyze stories as forms of knowledge that are not often valued. Second, students can evaluate and practice storytelling as a strategy for social change. For each broad theme, I briefly discuss relevant scholarly work to situate the various applications presented below. The paper is organized in a way to make the content easily applied to teaching, and thus provides limited scholarly or theoretical discussion. In the sections that follow, I present models for how narrative can build inclusion in the classroom and promote engagement in the community.

\section{Narrative as Knowledge: Stories and Power}

First, I seek to establish stories or narratives of lived experience as a critical way of building knowledge that expands epistemological paradigms of social science fields (Yanow, 2003; Carbado \& Roithmayr, 2014). In particular, I focus on how narrative is particularly relevant for marginalized groups whose lived experiences are often under- or mis-represented. Secondly, while acknowledging the importance of stories, I emphasize their limitations when approached uncritically.

\section{Concepts}

Relevance to marginalized groups. Pushing back on rigid data regimes that elevate quantitative forms of data, critical race scholars have situated the counternarratives or stories of marginalized groups as alternative forms of data that subvert dominant representations that pervade public policy, social institutions, research, or popular media (Olsen, 2014; Graham, 2007). The stories of marginalized groups may be written off as "anecdotal" or reflecting purely personal experiences. Studying narrative critically also allows students to understand the various ways in which power may be wielded outside of formal positions of authority. For students interested in social change, it is through stories that they may begin to grasp the value of cultural resources in addition to other types of resources. For example the tesimonio at the heart of I, Rigoberta Menchu (1983), can be understood in light of larger indigenous and solidarity organizing on a global scale. In increasingly diverse classrooms where students may not see themselves represented in curricular materials, the inclusion of stories may help foster greater inclusion.

Limitations. Just as they have power to subvert the status quo, students should also understand how stories may perpetuate it. Even well-intentioned groups have utilized storytelling in a way that has perpetuated negative stereotypes (Fernandes, 2017). For example, undocumented student activists have recognized how positioning themselves as the "good" or "deserving" immigrants who are pursuing their education may render less high achieving members of their community as "bad immigrants." Similarly, stories may obscure larger structural problems and perpetuate dominant tropes or stereotypes if they are not adequately contextualized (Ladson-Billings, 2013). 


\section{Applications}

Syllabi. One fundamental way to indicate the importance of narrative, is for students to engage it as a text on the course syllabus. Incorporating readings into our syllabi that are narrative-based (whether in writings, film, podcasts, etc.), helps students see these stories as valuable and meaningful in an academic context. In addition to analyzing examples of storytelling from recent events, instructors may consider guest speakers who are not just subject matter experts, but those who can share powerful lived experiences as well. Firsthand accounts from activists associated with recent movements, from Occupy Wall Street to BlackLivesMatter, can help connect personal narratives with larger contexts. Examples from each are cited below.

Assessments. Aside from reading or analyzing narratives, students may also be invited to share their own stories during in class discussions or through written assignments. Facilitated discussions to activate prior knowledge, journaling, and portfolio projects are particularly suited for this type of storytelling. Additionally, rubrics for written assessments can be formulated to consider how personal experience may be presented as evidence. The appendix includes such a rubric that evaluates students on their ability to synthesize evidence. Thus, students come to see their ability to engage their lived experience, reflect upon it, and articulate its relevance to larger phenomenon as a valuable skill. In the subsequent sections, I expand on the ways in which political advocacy has come to rely more heavily on this very type of storytelling for social change. While much academic writing eschews first person pronouns, teaching students how to effectively incorporate their personal experiences can allow them to also write for various audiences.

\section{Narrative for Social Change: Leadership and Mobilization}

In this section, I explore how instructors may present storytelling as an organizing or social movement tactic to galvanize people to action (Mayer, 2014). While more overt attempts at social change or resistance often garner the most attention, students may also appreciate the subversive and cultural politics of storytelling or narrative (Scott, 1985; Auyero, 2004). Those who study social change have come to understand biography as an essential component to understanding activism and more scholarly attention may be paid to lived experience (Jasper, 2008). In the rest of the section, I discuss the nuances of narrative in social movement strategy.

\section{Concepts}

Narrative as art and science. As opposed to strategic messaging or issue framing strategies that are very direct, narrative typically can offer greater ambiguity and leave more room to interpretation (Polletta, 2009). As a result, stories are more adept at capturing complexity of social contexts (Ganz, 2009). Further, narrative strategies can be exercised on various levels, whether through polished video advertisements or through carefully honed statements in public hearings. Given that narrative often draws on the heartstrings of the audience, we may also analyze which contexts are more receptive to storytelling as a social change strategy (Polletta \& Chen, 2012). Students may explore questions like: under what circumstances are policymakers likely to respond to narratives? A larger storytelling industry comprised of nonprofits and for-profit 
communications firms has emerged (Fernandes, 2017). Thus, narrative is both an art and science that students may be prepared to consume, analyze, and critique more effectively.

\section{Applications}

Story of self. Storytelling is also an important form of reflection that allows future leaders to take stock of their own lived experiences and what drives them to take action. Building on the work of Ganz (2012), I introduce the "Story of Self" as a tactic that can help students make sense of their lived experience, the contexts that have shaped them, and the actions they are taking in response. For Ganz, narrative is our way of emotionally connecting values that move us to action ("The Why" as opposed to "The What" or "The How"). A story of self should recount major milestones in the speaker's life history, but emphasize the critical junctures at which they made a choice. Choices, Ganz reminds us, are driven by our values. It may come as no surprise that Ganz advised the Obama 2008 campaign where many of these tactics were on display in the candidate's speeches. Such activities may be particularly useful in upper-level courses as students are embarking on their future plans and exploring various modes of civic engagement. In such cases, instructors may facilitate workshops or activities that help students craft a story of self. To encourage students, instructors may themselves share their own stories of how they came to their work. Building on the Story of Self, Ganz also outlines how leaders must craft a Story of Us and a Story of Now, that foster a sense of inclusion and immediacy for groups to take action.

Analysis. Providing students with actual examples of narratives crafted by activists can help them critique their usage and understand this work more strategically. When viewing recent examples of storytelling by immigrant rights groups, LGBTQ activists, gun control activists or others, questions students may explore include: Are campaigns more effective when they use "hard data" vs. narrative? What makes the speaker credible/non-credible? Who appears to be the intended audience? What norms or values does the story appear to reference? What are they calling upon us to do? Who appears to be responsible for this situation? These questions require students to adopt a critical lens and to also recognize assumptions or biases they may have as well.

In addition to emphasizing the power of stories, it is important to remind students that such strategies are not enough on their own to win social change (Ryan \& Gamson, 2006). Indeed, highly visible or glitzy social media campaigns may obscure the more complex and behind-the-scenes aspects of grassroots organizing needed to make them most effective (Schradie, 2014; Tufecki, 2017). Thus, even as we introduce students to the power of narrative for social change, we must emphasize that simply finding the right story will not "do the trick." Instead, students should understand public narrative as interconnected with a host of other strategies that organizers or activists undertake in pushing for social justice.

\section{Classroom Resources}

- Adichie, "The Danger of a Single Story." The popular TED talk drives home the power of narrative by focusing on the implications of dominant narratives and how critical it is for marginalized groups to be able to be the authors of their own stories. 
- Everytown for Gun Safety. The organization has plenty of videos that tell personal stories as well as others that even dabble in fictional narratives. These videos are a part of what the organization calls its "broader cultural portfolio, which uses every available cultural vehicle to engage and activate people on gun violence prevention."

- Ganz, "Public Narrative, Collective Action, and Power." This straightforward article on the role of narrative in leadership and mobilization has helpful illustrations and figures that can be easily reproduced in a worksheet/slide for in-class reading/activities.

- Garza, "A Herstory of the \#BlackLivesMatter Movement." A look back on the emergence of one of the most potent hashtags and movements in recent history told from the perspective of one of the women who first introduced it.

- Naomi Wadler's speech. At "March for Our Lives," the 11 year-old spoke about bringing Black women into the conversation around gun violence, and addressed those who would dismiss her voice because of her age, race/gender, etc.

- Rosa Parks. Perhaps one of the most contested stories of social change that has been told/retold in various articles and books.

- Rubric. This is a generic writing rubric that includes "lived experience" as a form of evidence that can be used in synthesizing source materials.

- Story of self: examples. Posted to the Bill Moyers site that accompanies an interview with Ganz, these are very brief and clearly crafted examples. You can find plenty of others online.

- Story of self: worksheets. Various sites include worksheets to help facilitate the development of a story of self by helping participants focus on the areas of life that are most important to them and the choices they have had to make.

- We are the 99\%. A hashtag/social media campaign associated with Occupy Wall Street emphasized the ways in which seemingly "average" Americans came to see themselves within the broader movement with handwritten messages that addressed their experiences with inequality in various forms. 


\section{References:}

Auyero, J. (2004). When everyday life, routine politics, and protest meet. Theory and Society, 33: 417-441.

Carbado, D. \& Roithmayr, D. (2014). Critical Race Theory meets social science. Annual Review of Law and Social Science 2014 10:1, 149-167

Fernandes, S. (2017). Curated stories: the uses and misuses of storytelling. New York: Oxford.

Ganz, M. (2011). Public narrative, collective action, and power. In S. Odugbemi \& T. Lee (Eds.), Accountability through public opinion: from inertia to public action (pp. 273-289). Washington, D.C: The World Bank.

Graham, B. L. (2007). Toward a critical race theory in political science: A new synthesis for understanding race, law, and politics. African American Perspectives on Political Science. Philadelphia, PA: Temple University, 212-231.

Jasper, J. (2008). The art of moral protest: culture, biography, and creativity in social movements. University of Chicago Press.

Ladson-Billings, G. (2013). Critical race theory-What it is not! In M. Lynn \& A. Dixson (Eds.), The handbook of critical race theory in education (pp. 34-47). New York, NY: Routledge.

Mayer, F. (2014). Narrative Politics: Stories and Collective Action. New York: Oxford.

Menchú, R. (2010). I, Rigoberta Menchú: An Indian woman in Guatemala. Verso Books.

Olsen, K. (2014). Telling our stories: Narrative and framing in the movement for same-sex marriage. Social Movement Studies, 13(2), 248-266.

https://doi.org/10.1080/14742837.2013.842464

Polletta, F. (2009). It was like a fever: Storytelling in protest and politics. University of Chicago Press.

Polletta, F., \& Chen, B. (2012). Narrative and social movements. In J. C. Alexander, R. N. Jacobs, \& P. Smith (Eds.), The Oxford handbook of cultural sociology. https://doi.org/10.1093/oxfordhb/9780195377767.013.18

Schradie, J. (2014). Bringing the organization back in: Social media and social movements. Berkeley Journal of Sociology. http://berkeleyjournal.org/2014/11/bringing-the-organizationback-in-social-media-and-social-movements/.

Scott, J. (1985). Weapons of the Weak: Everyday Forms of Peasant Resistance. New Haven: Yale University Press 
Tufecki, Z. (2017). Twitter and tear gas: The power and fragility of networked protest. New Haven: Yale University Press.

Yanow, D. (2003). Interpretive empirical political science: What makes this not a subfield of qualitative methods. Qualitative Methods, 1(2), 9-13. 